$12-2016$

\title{
Book Review: A History of Rwandan Identity and Trauma: The Mythmakers' Victims
}

James J. Snow

Loyola University Maryland

Follow this and additional works at: https://digitalcommons.usf.edu/gsp

\section{Recommended Citation}

Snow, James J. (2016) "Book Review: A History of Rwandan Identity and Trauma: The Mythmakers' Victims," Genocide Studies and Prevention: An International Journal: Vol. 10: Iss. 3: 88-91.

DOI:

http://doi.org/10.5038/1911-9933.10.3.1430

Available at: https://digitalcommons.usf.edu/gsp/vol10/iss3/9

This Book Review is brought to you for free and open access by the Open Access Journals at Digital Commons @ University of South Florida. It has been accepted for inclusion in Genocide Studies and Prevention: An International Journal by an authorized editor of Digital Commons @ University of South Florida. For more information, please contact digitalcommons@usf.edu. 
Book Review: A History of Rwandan Identity and Trauma:The Mythmakers' Victims

\author{
James J. Snow \\ Loyola University Maryland \\ Baltimore, MD, USA
}

\author{
A History of Rwandan Identity and Trauma: The Mythmakers' Victims \\ Randall Fegley \\ Lanham, Lexington Books, 2016
}

169 Pages; Price: $\$ 80.00$ Hardcover

Reviewed by James Snow

Loyola University Maryland

Only after the genocide of 1994 did Rwanda capture the attention of the world that lies beyond the Great Lakes region of East Central Africa. Even the genocide itself in which up to 1,000,000 Rwandans were slaughtered in just 100 days was ignored by the United Nations Security Council (UNSC), the United States, France, and Belgium. In the 22 years following the genocide there has emerged a vast body of literature and film focused on the genocide and its aftermath. Journalists, filmmakers, and aid-workers have produced thousands of documents concerned with the genocide. And while academic presses have published scholarly monographs on Rwanda, Johan Pottier worried in 2002 that filmmakers, journalists, and their kin dominated the conversation but may not have been in the best position to provide the context that would help to foster a deeper and more nuanced understanding of the traumas that antedated the genocide, the genocide itself, and the trauma that ensued long after the killing stopped. ${ }^{1}$

Randall Fegley's monograph, A History of Rwandan Identity and Trauma: The Mythmakers' Victims, is a welcome contribution to enriching our understanding of the depth and complexity of the genocide. Although the main focus of the book is not the 1994 genocide, his analysis does provide worthwhile insights that have direct bearing on the trauma of 1994 and the struggles that plague Rwanda well into the present day. According to Fegley, the "book is not about atrocities, but rather the Rwandan identity and the internal and external myths that have confined and directed it," and he argues that "the mythologies affecting the Rwandan experience have tended to emphasize deadly, political narratives." 2 The lens of mythology is crucial to understanding how a people and a nation see themselves and construct the "Other." Fegley fruitfully borrows Duncan Bell's notion of a "mythscape" - "a discursive realm in which the myth of a nation are forged, transmitted, negotiated and reconstructed constantly," and he is correct to point out that myths, as distinct from historical accounts of the past, are tremendously powerful in the construction of a national identity. ${ }^{3}$ And he astutely emphasizes that myths are not necessarily tied to the historical record; rather, they are often part of an oral tradition told by storytellers who take the liberty of seeing the past in terms of the present.

In his introductory chapter, in addition to offering a précis of the argument, Fegley offers a cursory overview of the country. While he is right to claim that the people and land that is Rwanda have been largely ignored, his four-page description is taken mostly from a U.S. Army publication from 1986 and the CIA World Fact Book. If the book is intended for a general audience unacquainted with Central Africa, the description is alarmingly brief and schematic. If the book is intended for scholars, they will already be familiar with this information.

In Chapter 1 Fegley points out that little is known of the early history of the area that was to become modern Rwanda and Burundi-countries with similar ethnic and linguistic demographics. Nevertheless, and as he shows, there is a well-entrenched mythology concerning the origins of

\footnotetext{
${ }^{1}$ Johan Pottier, Re-Imagining Rwanda: Conflict, Survival and Disinformation in the Late Twentieth Century (Cambridge: Cambridge University Press, 2002).

${ }^{2}$ Randall Fegley, A History of Rwandan Identity and Trauma (Landham: Lexington Books, 2016), xiii, xiv.

${ }^{3}$ Fegley, History of Rwandan Identity and Trauma, xv; Duncan S.A. Bell, “Mythscape: Memory, Mythology and National Identity," British Journal of Sociology 54, March (2003), 63-81.
} 
the three ethnic groups: the Hutu majority, the Tutsi minority, and the relatively small group of Twa. According to the prevailing myth as told in the epic poems of the Ibitekerezo, Twa and Hutu occupied the area before Tutsi arrived from the north to establish order in the region beginning in the eleventh century. Gihanga - the "founding" Tutsi king of oral tradition-was venerated in Rwandan mythology well into the twentieth century, and with it a narrative of Tutsi superiority. The mythological narrative of Tutsi superiority was further codified during the colonial rule of the Germans and later the Belgians. With the advent of written history, the hegemony of the narrative of Tutsi superiority became even stronger with the invention of the Hamitic hypothesis. This hypothesis, promulgated by among others, Oskar Baumann and Charles Gabriel Seligman, claims that the Tutsi were descendants of the Hamites, a racially distinct and racially superior Caucasoid people who, the hypothesis claimed, descended from the north bringing civilization to East Central Africa. ${ }^{4}$

In Chapter 2, the longest of the five chapters, Fegley summarizes the complicated history of the rise of Hutu power beginning with the Belgian deportation of Mwami Yuhi Musinga in 1931 (in effect, marking the end of the Tutsi dynasty) through the 100 days of slaughter in 1994. Most of what is presented in the first two-thirds of the chapter will be familiar to scholars and students of the genocide and relies on earlier accounts by scholar, Gérard Prunier and journalist Philip Gourevitch. ${ }^{5}$ A discussion of myth, a theme prominent in the introduction and first chapter, is nearly absent in this chapter. Fegley devotes one paragraph to the publication of the Hutu Manifesto (1957) which reversed the Hamitic hypothesis and cast the Tutsi as the original foreign invaders from the north who tyrannized the Hutu. Fegley writes: "A new canon of mythology had replaced the old." 6

Chapter 3, a relatively brief chapter, describes the aftermath of the genocide following the victory of the Rwandan Patriotic Army under the leadership of Paul Kagame, and the establishment of a new government. Kagame became president of Rwanda in 2000. Under Kagame's leadership, the International Criminal Tribunal for Rwanda (ICTR) and the gacaca courts tried hundreds of thousands of perpetrators. Kagame is not without his critics, but he is seen by many as being instrumental in bringing economic prosperity and a degree of unity and reconciliation to postgenocide Rwanda. While most of the chapter describes Rwanda's journey toward justice, reconciliation, and stability, Fegley is right to point out that in the wake of trauma in which the vast majority of survivors were witness to extreme violence and lost family members, divisive mythologies are likely to persist. Confronting and redressing these persistent divisive mythologies, in Fegley's view, is the responsibility of parents and educators. The pre-colonial and colonial education system perpetuated and reinforced group stereotypes, first reinforcing the favoring of Tutsi, and after the Hutu Revolution favoring the Hutu. It speaks volumes that Rwanda did not teach its own history for 13 years following the genocide; instruction in history began anew in 2007 with a new and carefully negotiated curriculum.

Fegley's fourth chapter describes in some detail the development of the new curriculum negotiated by policy makers, educators, and curriculum experts within Rwanda in conjunction with consultants from the University of California-Berkley. This chapter helps to illuminate the politics of national curriculum development, a task made especially difficult given Rwanda's traumatic past and its quest for national unity.

As would be hoped for and expected, in his concluding chapter, Fegley looks forward, searching for paths to reconciliation, social harmony, and stability in Rwanda. He briefly compares Rwandan state-level political initiatives to the initiatives in other countries including countries that have experienced colonial and post-colonial trauma. In the end, he seems skeptical of the efficacy of structural political initiatives as the power of mythologies and ideologies that embrace binaries of self and "Other" are not easily dispelled; too often a group will self-identify as a victim

\footnotetext{
${ }^{4}$ Oskar Baumann, Durch Massailand zur Nilquelle (Berlin: D. Reimer, 1894); C.G. Seligman, Races of Africa, $4^{\text {th }}$ ed. (London: Oxford University Press, 1966).

${ }^{5}$ Gérard Prunier, The Rwanda Crisis: History of a Genocide (New York: Columbia University Press, 1995); Philip Gourevitch. We Wish to Inform You that Tomorrow We Will be Killed with Our Families (New York: Picador, 1999).

${ }^{6}$ Fegley, History of Rwandan Identity and Trauma, 31.
} 
group. Referencing Mahmood Mamdani's When Victims Become Killers, Fegley claims, "Yesterday's desperate victims became today's convinced perpetrators." ${ }^{7}$

Fegley's final two pages take a most unexpected turn. Here, Fegley introduces the early work of Stephen Karpmen who introduced the notion of a Drama Triangle in the field of transactional analysis. ${ }^{8}$ The Drama Triangle was introduced by Karpmen as a way of characterizing dysfunctional relationships, and recent work in transactional analysis (here he cites Patricia Morgan ${ }^{9}$ ) is designed to help people break out of dysfunctional personal relationships. He is skeptical of what can "be accomplished by just sending directives from the top or bringing in foreign experts."10 It is somewhat surprising that this claim does not receive more attention. Scott Straus, for example, has recently shown that "founding narratives" perpetrated by political elites have tremendous power to both provoke and sustain genocidal violence, and it seems clear that narratives perpetrated by political elites would be equally powerful in advancing the cause of reconciliation. ${ }^{11}$ Instead, Fegley places the onus on "writers, artists, clergy, teachers, storytellers and parents," who, he claims, could use Morgan's framework to help facilitate the development of "reconciliatory narratives emanating from the grassroots." ${ }^{12}$

This is a short book; subtracting pages containing endnotes, the bibliography, and index, it is just over 100 pages. And it is written in a style that makes it accessible to a general audience with little familiarity with the land and people of Rwanda, Rwanda's history, or the genocide and its aftermath. Despite its brevity, however, its scope is vast. And because of its vast scope, at times it lacks thematic integrity. While the book purports to be concerned with myths that ground the Rwandan identity, there are sections of the book that do not connect to this theme in any evident way. For example, 10 pages at the end of the chapter on the genocide are devoted to a review of books, articles, reports, and films about the genocide, including a discussion of the controversies surrounding the film Hotel Rwanda. The chapter on the development of a new history curriculum post-genocide is replete with details concerning the development of a new curriculum, but does not fully deliver on the promise of the chapter title, "Creating a Competing Mythology."

The book contains nearly 500 footnotes - a testament to its breadth-but many of the more important pieces of scholarship cited are only briefly acknowledged but not discussed in any detail. Given the brevity of the book, it is regrettable that Fegley does not more carefully engage this recent scholarship on some of the same themes that are central to his study. Two examples are worth noting. In the chapter on education Fegley does quote from Elisabeth King's seminal work, From Classrooms to Conflict in Rwanda. ${ }^{13}$ However, he does not take on one of her central arguments to the effect that the post-genocide educational system in Rwanda is in important ways continuous with the colonial system in that it continues to perpetuate the antagonisms she shows to be part of colonial education. Second, there is emerging a body of scholarship on the complex intersection of myth and history in relationship to the construction of national identities. While Stefan Berger writes about this relationship in the case of modern Europe, his analysis of the relationship between myth and history could well illuminate the difficulties facing Rwanda. ${ }^{14}$

One final concern, and one alluded to earlier, lies in his introduction of Karpmen and Morgan's model for triangulating interactions as a resource for promoting peace and reconciliation. While he is to be commended for looking well outside the conventional box for resources for promoting

\footnotetext{
${ }^{7}$ Mahmood Mamdani, When Victims Become Killers: Colonialism, Nativism, and the Genocide in Rwanda (Princeton: Princeton University Press, 2001); Fegley, History of Rwandan Identity and Trauma, 124.

${ }^{8}$ Stephen Karpman, A Game Free Life (Little Rock AR: Drama Triangle Productions, 2014); Fairy Tales and Script Drama Analysis" Transactional Analysis Bulletin, 7 (April 1968).

${ }^{9}$ solutionsforreselience.com

${ }^{10}$ Fegley, History of Rwandan Identity and Trauma, 125.

${ }^{11}$ Scott Straus, Making and Unmaking Nations: War, Leadership, and Genocide in Modern Africa (Ithaca: Cornell University Press, 2015).

${ }^{12}$ Fegley, History of Rwandan Identity and Trauma, 126.

${ }^{13}$ Elizabeth King, From Classroom to Conflict in Rwanda (Cambridge: Cambridge University Press, 2002).

${ }^{14}$ Stefan Berger, "On the Role of Myths and History in the Construction of National Identity in Modern Europe," European History Quarterly, 30(3), (2009), 490-502.
} 
reconciliation, his proposal, precisely because of it novelty, demands far more than two and a half pages of explanation.

Overall, while the book offers some important insights into a political situation in Rwanda that remains fraught, in the end, it does not fully deliver on its promise to reveal and analyze the myths that have shaped, and continue to shape, the Rwandan national identity. 